\title{
MANAGEMENT OF CHOLEDOCHAL CYST
}

\section{Tratamento do cisto de colédoco}

\author{
Orlando Jorge Martins TORRES, Erica Sampaio BARBOSA, Edson Dener Zandonadi FERREIRA, \\ Poliana Cristina Oliveira MOREIRA, Patricia Brandão PANTOJA
}

\begin{abstract}
Torres OJM, Barbosa ES, Ferreira EDZ, Moreira PCO, Pantoja PB. Management of choledochal cyst. ABCD Arq Bras Cir Dig 2007;20(3):205-7. ABSTRACT - Background - Choledochal cysts are rare diseases in adults. The risk of malignant transformation is well documented to be age-related and early complete cyst excision is currently advocated. Type IVa cyst management is more controversial. Extensive intrahepatic involvement of the biliary system may preclude complete excision. Aim - The aim of this study was to present a case of type IVa choledochal cyst in a young female patient. Case report - An 18-year-old female, complaining of right upper quadrant pain, nausea, vomiting, fever, and jaundice was admitted. The diagnosis of type IVa choledochal cyst was made by computerized tomography. The patient was underwent cholecystectomy, excision of the anterior wall of the cyst, and Roux-en-Y hepaticojejunostomy. No postoperative complication was noted and the patient was discharged five days after operation. Conclusion - Total cyst excision is the ideal treatment of choledochal cysts in adults. However, in IVa type, due to the extensive intrahepatic involvement of the biliary system, the anatomy of the cyst, and the surgeon's judgment will determine the surgical approach taken for the patient.

HEADINGS - Common bile duct. Cysts. Choledochal cyst. Cholecystectomy.
\end{abstract}

\section{INTRODUCTION}

Choledochal cyst are rare congenital dilatations of the biliary tree, which can be extrahepatic, intrahepatic or both. They occur more commonly in Asian, female (4:1), infant patients. These cysts are clinically important because of their attendant complications of recurrent cholangitis, biliary stricture, choledocholithiasis, recurrent acute pancreatitis, and malignant transformation ${ }^{1,2}$. The first classification of choledochal cyst presented by Alonzo-Lej et al. ${ }^{3}$ was subsequently altered by Todani et al. ${ }^{4}$. The Todani's classification system of choledochal cyst is widely accepted and currently used to guide specific diagnosis and treatment, and to predict the natural history of choledochal cyst. Five main types of choledochal cysts are recognized ${ }^{4}$.

The risk of malignant transformation is well documented to be age-related and early complete cyst excision is currently advocated. However, in adults diagnosis is often delayed because of the nonspecific and intermittent symptoms ${ }^{1,5}$. The purpose of the present study was to present a case of surgical treatment of type IVa choledochal cyst.

From the Department of Surgery, Federal University of Maranhão, São Luiz, MA, Brasil

Correspondence to: Orlando Jorge Martins Torres, e-mail: o.torres@uol.com.br

\section{CASE REPORT}

An 18-year-old female, complaining of right upper quadrant pain, nausea, vomiting, and jaundice was admitted. Five days later presented fever $\left(40^{\circ} \mathrm{C}\right)$, chills, itching, and signals of recurrent cholangitis. There was no history of previous abdominal surgery. Physical examination was unremarkable except for clinical jaundice. The patient had mildly deranged liver function tests. The serum bilirubin was $29 \mu \mathrm{mol} / 1$, alkaline phosphatase was $171 \mathrm{UI} / 1$, alanine transaminase was $145 \mathrm{UI} / 1$, and amylase was $133 \mathrm{U} / 1$.

The diagnosis was made by ultrasound and computed tomography that showed combined intrahepatic and 5.4 $\mathrm{cm}$ extrahepatic dilatation of the bile duct (type IVa choledochal cyst according to Todani's classification system). The gallbladder's wall was thin, no gallstone was found and the pancreas was normal (Figures 1 and 2). The patient was diagnosed with choledochal cyst and underwent surgery. The operative treatment included cholecystectomy and excision of the anterior wall of the cyst that was send to histological study. The biliary continuity was restored by Roux-en-Y hepaticojejunostomy. 


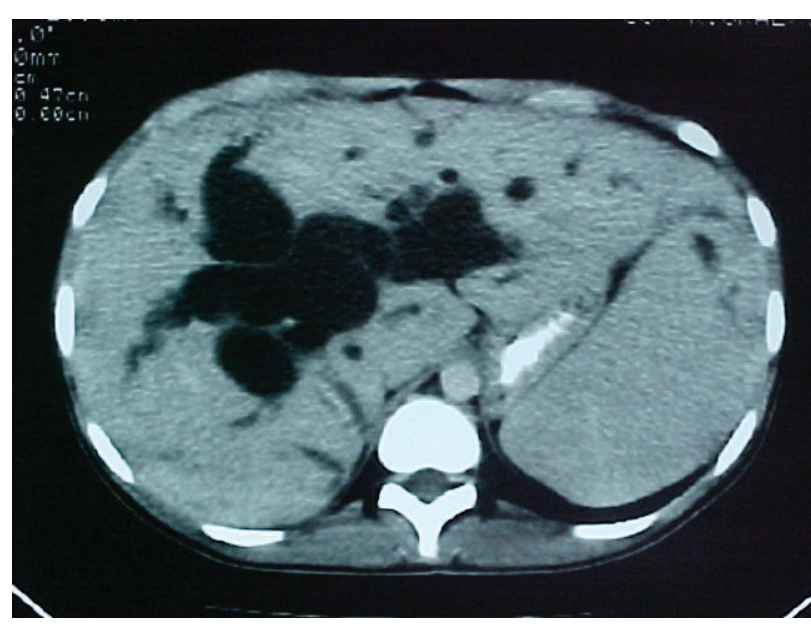

FIGURE 1 - Computed tomography shows intra-hepatic bile duct dilatation.

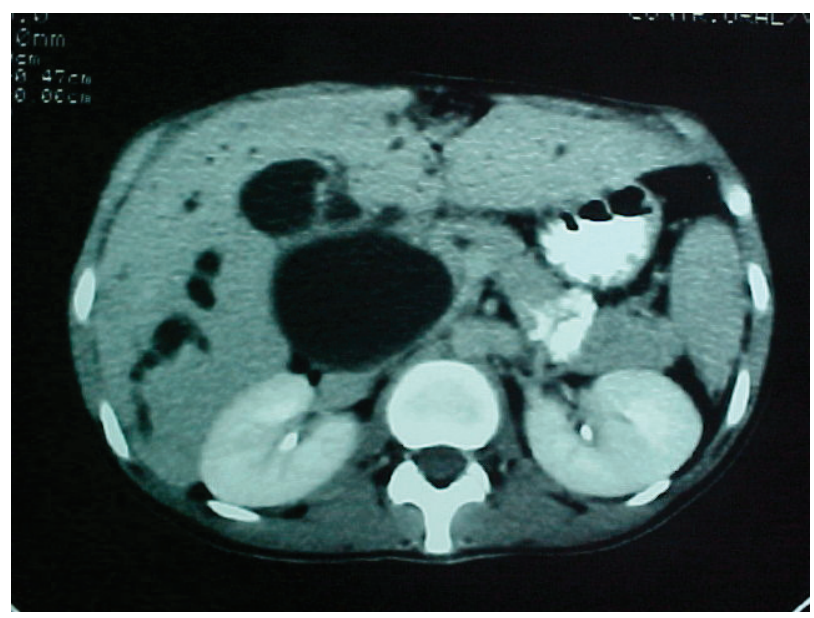

FIGURE 2 - Computed tomography shows a $5.4 \mathrm{~cm}$ extra-hepatic dilatation of the bile duct.

No postoperative complication was noted and the patient was discharged five days after operation. Pathology findings of the anterior wall of the choledochal cyst resected demonstrated erosion of the mucosa, chronic inflammation, and fibrosis in the cyst wall. After one year of followup there was no evidence of jaundice, cholangitis, or pancreatitis to suggest possible complication of the biliary anastomosis.

\section{DISCUSSION}

Choledochal cysts are congenital biliary tract anomalies of unclear pathogenesis. Two predominant theories exist, which are not necessarily exclusive.

The first, is that of long common channel and the second, of distal obstruction. The long common channel results in the junction of the pancreatic and biliary ducts outside the duodenal wall and proximal to the sphincter of Oddi mechanism, therefore allowing pancreatic juice reflux into the common bile duct. Inflammation and eventual denuding of the epithelial lining weakens the duct wall and cystic dilatation occurs ${ }^{2,5,6}$.
The second, is that of duct obstruction resulting from several possible mechanisms: sphincter of Oddi dysfunction, inadequate autonomic innervation, or unequal vacuolization during organogenesis ${ }^{2,6}$.

Different pathogenetic mechanisms are probably responsible for the different cyst types and may also be different in adults and children. Most choledochal cysts are diagnosed in childhood, however, up to $20 \%$ of them are presented in adults. They are more prevalent among females in a 4:1 ratio. The type IVa cysts are recognized to be more prevalent among adults and have been reported to have a prevalence of $2 \%$ to $39 \%$. Within North America, the relative prevalence of type IVa cysts in larger series ranges from $14 \%$ to $60 \%$. This wide range of type IVa cyst may be related to the difficulty of diagnosis due to an underestimation of the intrahepatic duct involvement. Presentation in adults is nonspecific and often leads to delay in diagnosis. The classic triad of abdominal pain, right upper quadrant mass, and jaundice more prevalent in pediatric population, is reported to occur in $2 \%$ to $38 \%$ of patients. Diagnosis of choledochal cyst in adults cannot generally be made on the basis of symptomatology. Ultrasound is the preferred initial method of investigation. Identified cysts should then be investigated with both tomography and retrograde endoscopic cholangiopancreatography to delineate the extent of cystic disease and assess for malignancy ${ }^{1,2,5,6}$.

According to Todani's classification system the choledochal cysts are classified in five types based on anatomical location. Type I cysts are confined to the extrahepatic bile duct and can be further subdivided into Ia involving the entire extrahepatic bile duct, Ib involving only a focal segment of extrahepatic bile duct, and Ic involving only the common bile duct. Type II cysts are true diverticula in the extrahepatic bile duct. Type III cysts are also referred to as choledochoceles and are confined to the extrahepatic bile duct within the duodenal wall. Type IV cysts are multiple and can have both an extrahepatic and intrahepatic component. These cysts can be further subdivided into type IVa involving both the extrahepatic and intrahepatic bile duct and type IVb involving multiple segmental dilatations of the extrahepatic bile duct. Type V cysts (Caroli's disease) are confined to the intrahepatic bile duct $^{2,3,4}$.

Malignancy is a well described complication of choledochal cysts. Malignancy rates are widely reported to be $14 \%$ to $18 \%$ in adults and greater than $50 \%$ in patients over 50 years, suggesting an increasing risk with increasing age. Delays in diagnosis and treatment are often years in duration, with a resultant increased risk in malignant degeneration. However, not all cysts have equal risk. Malignant degeneration occurs more often in type I and IV cysts and rarely in type II and III. To evaluate the probability of cancer developing, a 10 to 20 years follow-up is required. The site of malignant occurrence is generally within the cyst, but it has been reported to occur anywhere within the biliary tree. Jaundice should raise suspicion of malignancy in patients with choledochal cysts ${ }^{5,6}$.

The principle of surgical management of choledochal cysts by complete cyst resection and restoration of biliary 
drainage by Roux-en-Y hepaticojejunostomy is a concept that has gradually gained acceptance throughout the world. However, in spite of the importance of removing all of a choledochal cyst, many surgeons suggest excision with specific intervention directed by cyst type. Types I, II, and $\mathrm{IVb}$ can usually be managed with complete cyst excision and reconstruction with hepaticojejunostomy. In this case, type IVa cyst management is more controversial. Extensive intrahepatic involvement of the biliary system may preclude complete excision and wide hepatoenteric anastomosis is recommended. A surgeon must decide whether the risk of cancer that results from incomplete removal of the intra- hepatic and intrapancreatic choledochal cyst wall justifies the morbidity that may occur with total cyst excision. It is unclear if excision of only the extrahepatic cyst is sufficient to prevent malignant transformation ${ }^{2,5,6}$.

\section{CONCLUSION}

Total cyst excision is the ideal treatment of choledochal cysts in adults. However, in IVa type, due to the extensive intrahepatic involvement of the biliary system, the anatomy of the cyst, and the surgeon's judgment will determine the surgical approach taken for the patient.

Torres OJM, Barbosa ES, Ferreira EDZ, Moreira PCO, Pantoja PB. Tratamento do cisto de colédoco. ABCD Arq Bras Cir Dig 2007;20(3):205-7.

RESUMO - Racional - A doença de cistos de colédoco em adultos é rara. O risco de transformação maligna é bem documentado, sendo relacionado a idade, além da completa excisão do cisto ser aconselhada. O manuseio e gestão do cisto tipo IVa gera maior controvérsia. O envolvimento intrahepático extensivo do sistema biliar pode prevenir a sua completa excisão. Objetivos - Relatar o caso de um cisto de colédoco do tipo IVa em paciente feminina. Relato de caso - Paciente feminina, 18 anos de idade, foi admitida com queixa de dor no quadrante superior direito, náusea, vômitos, febre e icterícia. O diagnóstico de cisto de colédoco do tipo IVa foi realizado através de tomografia computadorizada. A paciente foi submetida à colecistectomia, excisão da parede anterior do cisto e hepatojejunostomia em Y-de-Roux. Nenhuma complicação pós-operatória ocorreu e a paciente recebeu alta após 5 dias da operação. Conclusão - A excisão total do cisto é o tratamento ideal para cistos de colédoco em adultos. Entretanto, no cisto do tipo IVa, devido ao seu envolvimento intra-hepático extensivo do sistema biliar, sua anatomia e o discernimento do cirurgião determinarão a medida a ser tomada.

DESCRITORES - Ducto biliar comum. Cistos. Cisto de colédoco. Colecistectomia.

\section{REFERENCES}

1. Alonzo-Lej F, Revor WB, Pessagno DJ. Congenital choledochal cyst, with a report of 2, and an analysis of 94 cases. Surg Gynecol Obstet Int Abst Surg. 1959;108:1-30.

2. Jordan PH, Gross JA, Rosenberg WR, Woods KL. Some considerations for management of choledochal cysts. Am J Surg. 2004;187:434-9.

3. Lee KF, Lai EC, Lai PB. Adult choledochal cyst. Asian J Surg. 2005;28:2933.
4. Todani T, Watanabe Y, Nasure M. Congenital bile duct cysts: classification, operative procedures, and review of thirty-cases including cancer arising from choledochal cyst. Am J Surg. 1977;134:263-9.

5. Visser BC, Suh I, Way LW. Congenital choledochal cyst in adults. Arch Surg. 2004;139:855-62.

6. Wiseman K, Buczkowski AK, Chung SW, Francoeur J, Schaeffer D, Scudamore $\mathrm{CH}$. Epidemiology, presentation, diagnosis and outcome of choledochal cysts in adults in an urban environment. Am J Surg. 2005;189:527-31.

Conflito de interesse: não há

Fonte financiadora: não há

Recebido para publicação em: 22/02/2007

Aceito para publicação em: 23/05/2007 